\title{
Peningkatan Keterampilan Membaca Pemahaman Dengan Metode Survey, Question, Read, Recite Review (SQ3R) Di Sekolah Dasar
}

\author{
Yuyun $^{1}$ Yenni Fitra Surya ${ }^{2}$ Mufarizuddin ${ }^{3}$ \\ Pendidikan Guru Sekolah Dasar \\ Fakultas Ilmu Pendidikan \\ Universitas Pahlawan Tuanku Tambusai \\ e-mail : yuyunpgsd59@gmail.com
}

\begin{abstract}
Abstrak
Penelitian ini di latar belakangi rendahnya keterampilan membaca pemahaman peserta didik kelas V SDN 001 Batam Kota. Jenis penelitian ini adalah Penelitian Tindakan Kelas (PTK) yang dilaksanakan secara kolaboratif dengan guru kelas. Penelitian ini terdiri dari 4 tahap yaitu perencanaan, pelaksanaan, observasi dan refleksi. Subjek penelitian adalah peserta didik kelas V SDN 001 Batam Kota, terdiri dari 26 peserta didik terdapat 14 peserta didik laki-laki dan 12 peserta didik perempuan. Metode pengumpulan data menggunakan tes tertulis dan observasi. Tes tertulis digunakan untuk mengukur keterampilan membaca pemahaman sedangkan lembar observasi bertujuan mengamati aktivitas peserta didik dan aktivitas guru. Hasil penelitian menunjukkan bahwa penggunaan metode SQ3R dapat meningkatkan keterampilan membaca peserta didik kelas V SDN 001 Batam Kota. Hal ini ditunjukkan dengan adanya peningkatan jumlah peserta didik yang mencapai Kriteria Ketuntasan Minimum (KKM). Hal ini dapat dilihat dari peningkatan nilai rata-rata dan nilai ketuntasan klasikal. Nilai ratarata dan persentase ketuntasan klasikal siklus I pertemuan I 66,92 dan 30,76\%, siklus I pertemuan II nilai ratarata 74,03 dengan persentase ketuntasan klasikal 46,15\% meningkat pada siklus II pertemuan I dengan ratarata nilai 79,80 dengan pesentase ketuntasan klasikal 73,07\% dan meningkat lagi menjadi 92,50 dengan persentase 92,30\% siklus II pertemuan II. Dengan demikian penggunaan metode SQ3R dapat meningkatkan kemampuan membaca pemahaman peserta didik kelas V di SDN 001 Batam Kota.
\end{abstract}

Kata Kunci: Survey, Question, Read, Recite, Review (SQ3R), Keterampilan Membaca Pemahaman

\begin{abstract}
The study was motivated by the low reading comprehension skills of grade V students of SDN 001 Batam Kota. This type of research is Classroom Action Research (CAR) which is carried out collaboratively with classroom teachers. This research consisted of 4 stages of planning, observation, observation and reflection. The research subjects were grade V students of SDN 001 Batam Kota which consisted of 26 students, there were 14 male students and 12 female students. Methods of data using written tests and observations. The written test is used to measure reading comprehension skills, forgetting the observation sheet, observing students' activities and teacher activities. The results showed that the use of the SQ3R method could improve the reading skills of grade V students of SDN 001 Batam Kota. This is indicated by an increase in the number of students who achieve the Minimum Completeness Criteria (MCC) and an increase in the class and classical average scores. The average value and the proportion of classical completeness in the first cycle of meeting I was 66,92 and $30,76 \%$, the first cycle of the second meeting the average value of 74,03 with classical completeness of $46,15 \%$ increased in the second cycle of the first meeting with an average value 79.80 and $73,07 \%$ classical completeness and increased again to 92,50 and $92.30 \%$ in the second cycle of meeting II. Thus the use of the SQ3R method can improve the reading comprehension skills of grade V students at SDN 001 Batam Kota.
\end{abstract}

Keywords: Survey, Question, Read, Recite, Review (SQ3R), Reading Comprehension Skill

\section{PENDAHULUAN}

Bahasa Indonesia adalah bahasa persatuan dan bahasa utama di Negara Kesatuan Republik Indonesia yang memiliki fungsi yang sangat dominan dalam segala aspek di dalam kehidupan bermasyarakat. Pendidikan Bahasa Indonesia merupakan salah satu aspek penting yang perlu diajarkan kepada peserta didik di Sekolah. Maka mata pelajaran ini kemudian diberikan sejak masih dibangku Sekolah Dasar (SD) karena dari situ 
diharapkan peserta didik mampu menguasai, memahami dan dapat mengimplementasikan keterampilan berbahasa, seperti membaca, menyimak, menulis dan berbicara.

Bahasa itu sendiri adalah sebagai alat komunikasi antar manusia. Permendiknas NO.22 Tahun 2006, (dalam Pepriana.P : 2016) mengatakan bahasa memiliki peran sentral dalam perkembangan intelektual, sosial, dan emosional peserta didik dan merupakan penunjang keberhasilan dalam mempelajari semua bidang studi. Pembelajaran Bahasa Indonesia diharapkan dapat membantu peserta didik mengenal dirinya, budayanya, dan budaya orang lain, dapat mengemukakan gagasan dan perasaan, berpartisipasi dalam masyarakat yang menggunakan bahasa tersebut serta dapat menggunakan kemampuan analitis dan imaginative yang ada dalam dirinya.

Bahasa Indonesia itu sendiri memiliki keterampilan berbahasa yang terdiri dari empat komponen utama, antara lain keterampilan berbicara, menyimak, membaca dan menulis. Salah satu keterampilan yang sangat penting untuk dimiliki oleh setiap individu adalah keterampilan membaca. Keterampilan membaca menjadi keterampilan yang sangat penting, karena keterampilan membaca menunjang keberhasilan peserta didik dalam proses belajar. Helman (Resmini, dkk. 2006:234) keterampilan membaca adalah interaksi dengan bahasa yang sudah di alih kodekan dalam tulisan. Wiryodijoyo, (dalam Syafaah \& Haryadi, 2016:24) menjelaskan keterampilan membaca merupakan keterampilan yang harus mendapat perhatian secara sungguhsungguh, karena keterampilan membaca bukanlah keterampilan yang langsung bisa ditransfer begitu saja, melainkan memerlukan proses latihan yang berkesinambungan. Keterampilan membaca selalu ada dalam setiap tema pembelajaran. Hal tersebut menunjukkan pentingnya penguasaan keterampilan membaca, karena keterampilan membaca merupakan salah satu standar menjadi dasar utama tidak hanya bahasa itu sendiri, tetapi juga bagi pelajaran lain. Aspek-aspek keterampilan membaca pemahaman menurut Razak (2007:12) meliputi : 1) gagasan pokok atau utama, 2) gagasan penjelas, 3) kesimpulan, 4) amanat atau pandangan pengarang. Permasalahan yang melatarbelakangi penelitian ini adalah masih banyak peserta didik yang kurang mampu dalam membaca pemahaman, hal ini terlihat dari peserta didik sulit dalam memahami dan menemukan gagasan utama yang terdapat teks bacaan, selanjutnya peserta didik juga tidak mampu menyebutkan gagasan penjelas dalam teks bacaan. Banyak diantara peserta didik tidak bisa menyimpulkan isi teks bacaan dengan baik, peserta didik juga sulit menentukan pesan atau amanat yang disampaikan pengarang. Selain itu, meskipun guru telah melakukan proses pembelajaran langsung, namun hal tersebut nampaknya belum berjalan efektif untuk meningkatkan pemahaman peserta didik dalam membaca.

Jika diperhatikan, permasalahan yang dialami peserta didik kelas $\mathrm{V}$ tersebut perlu mendapat solusi, sehingga perlu inovasi pembelajaran baru, peneliti menerapkan alternative tindakan untuk meningkatkan keterampilan membaca pemahaman dengan menerapkan metode yang tepat yaitu Metode Survey, Question, Read, Recite, Review (SQ3R).

SQ3R adalah metode pembelajaran yang menitik beratkan pada aktivitas membaca yang efisien dan membantu peserta didik untuk lebih konsentrasi terhadap teks yang dibaca, sehingga dapat mendorong peserta didik untuk lebih memahami apa yang dibacanya, terarah pada intisari yang tersirat dalam suatu buku atau teks. Soedarso (dalam Dalman, 2017:189) Metode SQ3R merupakan salah satu metode membaca untuk memahami isi bacaan yang menggunakan langkah-langkah secara sistematis dalam pelaksanaannya. Kason, (dalam Widianto \& Subyantoro 2015:4) dalam tesisnya menjelaskan bahwa metode SQ3R adalah "Study system that has been around for decades and is comprised of five steps: Survey, Question, Read, Recite, and Review." Pendapat tersebut menunjukkan bahwa metode SQ3R merupakan sistem belajar yang mengarahkan pembelajar pada lima langkah/tahapan. Langkah tersebut yaitu survey, question, read, recite, dan review. Sedangkan menurut Nugraheni \& Yunianta, 2018:125 Metode SQ3R adalah suatu metode pembelajaran yang berpusat pada (student centered) karena siswa dituntut berperan aktif untuk menggali dan memperkaya pemahaman mereka terhadap konsep-konsep yang dipelajari.

Tujuan Penelitian ini adalah untuk meningkatkan keterampilan membaca pemahaman peserta didik SDN 001 Batam Kota.

\section{METODOLOGI PENELITIAN}

Penelitian ini termasuk jenis penelitian tindakan kelas (PTK). Kurt Lewin, (dalam Surya, Y.F : 2018) Penelitian tindakan adalah suatu rangkaian langkah yang terdiri atas empat tahap, yakni perencanaa, tindakan, pengamatan, dan refleksi. Penelitian dimulai dari pertengahan bulan November sampai Desember 2019. Penelitian Tindakan Kelas ini dilaksanakan di SDN 001 Batam Kota. Subjek penelitian ini adalah peserta didik kelas V SDN 001 Batam Kota, dengan jumlah 26 peserta didik yang terdiri dari 14 peserta didik laki-laki dan 12 peserta didik perempuan.

Variabel penelitian ini terdiri dari variable $\mathrm{X}$ (variable bebas) yaitu metode Survey, Question, Read, Recite, Review (SQ3R) sedangkan variable Y (variable terikat) adalah keterampilan membaca pemahaman. Instrument penelitian ini adalah lembar observasi dan soal tes. Analisis data pada 
penelitian ini menggunakan data kuantitatif dan data kualitatif. Teknik analisis kualitatif digunakan untuk mendeskripsikan proses pembelajaran dengan menggunakan metode Survey, Question, Read, Recite, Review (SQ3R), yang terdiri dari aktivitas guru dan aktivitas siswa selama proses pembelajaran dengan metode SQ3R. menurut Miles dan Huberman (dalam Sugioyono 2011:338) bahwa analisis kualitatif adalah data yang mulai dengan menelaah data sejak pengumpulan data sampai seluruh data terkumpul.

Teknik analiasis kuantitatif digunakan untuk mengukur hasil keterampilan membaca pemahaman peserta didik setelah penerapan metode SQ3R. Analisis data dilakukan dengan melihat ketuntasan belajar peserta didik secara individual maupun klasikal. Peserta didik dikatakan tuntas belajarnya (ketuntasan individu) jika proporsi jawaban benar peserta didik $\geq 75$ dan suatu kelas dikatakan tuntas belajarnya (ketuntasan klasikal) jika dalam kelas tersebut terdapat $\geq 85 \%$ peserta didik yang telah tuntas belajarnya. (Depdikbud dalam Trianto, 2010:241)

\section{HASILPENELITIAN DAN PEMBAHASAN}

Penelitian ini dilakukan mulai dari pratindakan, siklus I dan siklus II. Penelitian ini dilakukan untuk meningkatkan keterampilan membaca pemahaman dengan menggunakan metode SQ3R pada peserta didik kelas V SDN 001 Batam Kota. Berdasarkan hasil penelitian dapat diketahui bahwa penelitian ini sudah mencapai kriteria keberhasilan. Berikut adalah pembahasan pelaksanaan metode SQ3R pada pembelajaran membaca pemahaman dan hasil tes membaca pemahaman dengan menggunakan SQ3R.

Sebelum dilaksankan metode SQ3R pada pembelajaran membaca pemahaman di kelas $\mathrm{V}$ SDN 001 Batam Kota terlebih dahulu dilakukan pratindakan. Pratindakan dialakukan untuk mengetahui kondisi awal peserta didik sebelum dilakukannya tindakan. Pada pratindakan ini guru mengajar dengan cara konvensional seperti biasa tanpa menggunakan metode SQ3R.

Hasil dari pratindakan menunjukkan bahwa keterampilan membaca pemahaman peserta didik masih kurang. peserta didik mengalami kesulitan dalam memahami isi bacaan, hal ini ditunjukkan dengan peserta didik kesulitan dalam menentukan kalimat utama dari suatu paragraf, peserta didik kesulitan dalam menjawab pertanyaan yang berasal dari bacaan, dan juga peserta didik mengalami kesulitan ketika diminta untuk menceritakan kembali bacaan yang telah mereka baca. Peserta didik juga kesulitan menentukan pesan atau amanat dari teks bacaan yang telah mereka baca.

Hasil lain yang ditunjukkan dari pratindakan adalah peserta didik belum berpartisipasi aktif dalam proses pembelajaran dan kurang antusias dalam mengikuti pembelajaran. peserta didik ramai sendiri dan menganggu temannya, suasana kelas menjadi sedikit gaduh dan kurang terkondisikan dengan baik sehingga menganggu konsentrasi peserta didik. Peserta didik kelas V SDN 001 Batam Kota memiliki kamampuan membaca pemahaman yang berbeda-beda, ada peserta didik yang memiliki keterampilan membaca pemahaman dengan baik sehingga dapat mencapi ketuntasan belajar dan ada pula peserta didik yang memiliki keterampilan membaca pemahaman dengan kurang baik sehingga belum dapat mencapi ketuntasan belajar.

Berdasarkan data yang diperoleh dari pratindakan, maka dilakukanlah penelitian tindakan membaca pemahaman dengan metode SQ3R yang diyakini dapat meningkatkan keterampilan membaca pemahaman peserta didik dan meningkatkan keaktifan serta antusias peserta didik selama proses pembelajaran. Penggunaan metode dalam pembelajaran membaca sesuai dengan pendapat Dalman (2013:5) yang menyatakan bahwa guru sebaiknya mengajarkan kepada siswa tentang strategi, metode, dan teknik membaca yang baik sehingga siswa mampu memahami isi bacaan dengan baik pula.

Penelitian ini dilakukan dalam dua siklus. Setiap siklus dilakukan dalam dua pertemuan. Tindakan siklus I adalah awal penggunan metode SQ3R dalam membaca pemahaman peserta didik kelas SDN 001 Batam Kota. Metode ini belum pernah diterapkan di kelas ini sebelumnya, sehingga ini merupakan metode yang baru dan asing bagi peserta didik. Pada siklus I metode SQ3R sudah dilaksanakan dengan runtut dan baik, namun kurang maksimal. Oleh karena itu dalam tahap refleksi dilakukan diskusi untuk menentukan tindakan perbaikan kekurangan yang terjadi pada siklus I sehingga pada siklus II penggunaan metode SQ3R dapat dilaksakan dengan lebih baik dan optimal.

Kegiatan awal yang dilakukan guru adalah mengenalkan serta menjelaskan metode SQ3R yang masih baru bagi peserta didik. Namun, sayangnya pada siklus I guru hanya menjelaskan secara sekilas tentang metode ini pada peserta didik. Guru hanya menyebutkan langkah-langkah SQ3R kemudian langsung mempraktekkannya bersama peserta didik. Hal tersebut membuat peserta didik masih kebingungan dengan metode SQ3R. Sehingga pada tahap refleksi siklus I diputuskan agar guru menjelaskan kembali metode SQ3R. Hasil refleksi tersebut dilakukan pada siklus II, guru telah menjelaskan kembali metode SQ3R agar peserta didik lebih mengerti langkahlangkah yang harus dilakukan.

Setelah tahap pengenalan terhadap metode SQ3R, tahapan selanjutnya adalah pembelajaran menggunakan metode SQ3R. Metode tersebut dimulai dari tahap survey. Pada siklus I tahap survey peserta didik telah dilakukan dengan baik. Peserta didik membaca secara sekilas teks bacaan 
yang telah didapat. Membaca sekilas tersebut meliputi membaca judul bacaan, menghitung jumlah paragraf, serta membaca kalimat pertama dan terakhir setiap paragraf. Pada tahap survey juga dilakukan tanya jawab antara guru dan peserta didik mengenai hal-hal tersebut. Peserta didik mengikuti kegiatan survey sesuai arahan guru. Peserta didik antusias mengikuti kegiatan survey ditunjukkan dengan banyak peserta didik yang mau menjawab pertanyaan guru namun tidak dengan tunjuk jari, apabila diminta tunjuk jari tidak ada peserta didik yang mau. Pada siklus II tahap survey juga telah dilakukan dengan baik. Peserta didik lebih terarah dalam menjawab pertanyaan, peserta didik sudah aktif dan berani menjawab dengan tunjuk jari.

Kegiatan survey yang dilakukan peserta didik meliputi membaca judul, menghitung jumlah paragraf, membaca kalimat pertama dan terakhir setiap paragraf, serta membaca kalimat secara acak. Hal ini sesuai dengan yang disampaikan oleh Ngalimun (2014:62) yang menyatakan bahwa kegiatan survey dapat dilakukan dengan melihat judul, subjudul, paragraf dan lain sebagainya. Melalui tahap survey peserta didik menjadi tertarik dengan bacaan serta meningkatkan rasa ingin tahu siswa. Hal ini sesuai dengan pendapat Aris Shoimin (2014:194) yang menyatakan bahwa tahap survei pada awal pembelajaran dapat membangkitkan rasa ingin tahu siswa tentang materi yang akan dipelajari sehingga dapat meningkatkan motivasi siswa dalam belajar.

Tahap kedua dalam metode SQ3R adalah tahap question. Pada siklus I tahap question peserta didik belum berani mangacungkan tangan untuk mengajukan pertanyaan. Hanya ada tiga peserta didik yang berani mengacungkan tangan secara mandiri untuk bertanya, dan sisanya guru harus menunjuk peserta didik untuk membuat pertanyaan. Peserta didik belum dapat membuat pertanyaan dengan baik sehingga guru memberi contoh dan membantu dengan kata tanya sebagai pancingan. Karena peserta didik tidak berani untuk bertanya pada tahap refleksi diputuskan bahwa pada silus II peserta didik yang mau menjawab akan diberikan reward. Pemberian reward dimaksudkan agar peserta didik lebih aktif dan berani. Pada silus II banyak peserta didik yg bertanya, peserta didik menjadi aktif, banyak peserta didik yang berani. Pemberian reward ini dapat mengatifkan peserta didik sesuai dengan pendapat Brunner yang menyatakan bahwa reinforcement dan reward penting untuk meningkatkan perbuatan tertentu untuk membantu peserta didik mau mengulangi apa yang sudah dipelajari.

Tahap ketiga yaitu tahap read. Pada siklus I tahap read banyak peserta didik yang membaca dengan bergumam dan kurang sungguh-sungguh, beberapa siswa juga terlihat menganggu teman lainnya, bahkan ada siswa yang tidak membaca namun langsung melakukan tahap recite, yaitu mencari jawaban atas pertanyaan yang telah dibuat. Sehingga pada refleksi diputuskan untuk kegiatan membaca dilakukan dua kali, pertama melakukan kegiatan membaca secara bergantian dengan ditunjuk kemudian dilanjutkan dengan membaca dalam hati. Pada siklus II Tahap read, peserta didik membaca dengan sungguh-sungguh, semua sudah memperhatikan teks bacan, tidak ada yang ramai sendiri maupun mengganggu temannya.

Tahap selanjutnya adalah tahap recite. Pada siklus I tahap recite peserta didik dapat menemukan kalimat utama dan menjawab pertanyaan yang telah dibuatnya. Tahapan yang terakhir adalah tahap review. Pada silklus I tahap review peserta didik melakukan tanya jawab dengan guru mengenai garis besar isi teks. Hasil pekerjaan LKS belum dibahas dan peserta didik belum diberi kesempatan untuk meninjau ulang teks bacaan secara mandiri. Pada refleksi diputuskan pada saat review dilakukan pembahasan LKS dengan cara presentasi peserta didik, guru memberi kesempatan kepada peserta didik untuk meninjau ulang teks bacaan secara mandiri, dan bertanya jawab mengenai garis besar isi teks. Pada silus II tahap review hal yang dilakukan peserta didik meninjau ulang teks bacaan dengan presentasi peserta didik membahas LKS dan membacakan hasil ringkasan di depan teman- temannya, meninjau ulang teks bacaan secara mandiri, serta bertanya jawab mengenai garis besar isi teks.

Pada siklus I peserta didik masih kesulitan dalam membuat ringkasan atau kesulitan dalam menceritakan kembali teks bacaan yang telah dibacanya. Siswa hanya mampu menuliskan beberpa kalimat dari paragraf pertama. Sehingga pada tahap refleksi diputuskan untuk guru memberikan penjelasan mengenai cara menuliskan kembali secara ringkas teks bacaan yang telah dibaca. Pada siklus II peserta didik sudah dapat membuat kesimpulan dari teks bacaan yang telah dibacanya.

Hal di atas menunjukkan adanya peningkatan proses pembelajaran. Sementara itu, keberhasilan produk dalam penelitian ini ditunjukkan dengan peningkatan skor rata-rata peserta didik dan peningkatan jumlah peserta didik yang mencapai nilai $\geq 75$. Berikut adalah tabel hasil tes membaca pemahaman.

\begin{tabular}{|c|c|c|c|c|c|c|c|c|}
\hline \multirow[b]{3}{*}{ Kriteria } & \multicolumn{4}{|c|}{$\begin{array}{l}\text { Siklus } \\
\text { I }\end{array}$} & \multicolumn{4}{|c|}{ Siklus II } \\
\hline & \multicolumn{2}{|c|}{ Pertemuan 1} & \multicolumn{2}{|c|}{ Pertemua2 } & \multicolumn{2}{|c|}{ Pertemuan 1} & \multicolumn{2}{|c|}{$\begin{array}{l}\text { Pertemuan } \\
2\end{array}$} \\
\hline & 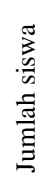 & 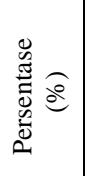 & 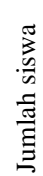 & 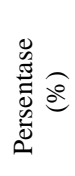 & 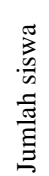 & 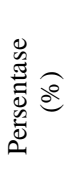 & 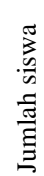 & 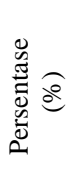 \\
\hline
\end{tabular}




\begin{tabular}{|l|c|c|c|c|c|c|c|c|}
\hline $\begin{array}{l}\text { Siswa } \\
\text { tuntas }\end{array}$ & 8 & $\begin{array}{c}33, \\
76\end{array}$ & 12 & $\begin{array}{c}46, \\
15\end{array}$ & 19 & $\begin{array}{c}73, \\
07\end{array}$ & 24 & $\begin{array}{l}92, \\
30\end{array}$ \\
\hline $\begin{array}{l}\text { Siswa } \\
\text { belum } \\
\text { tuntas }\end{array}$ & 18 & $\begin{array}{l}69, \\
24\end{array}$ & 14 & $\begin{array}{c}53, \\
84\end{array}$ & 7 & $\begin{array}{c}26, \\
92\end{array}$ & 2 & 7,69 \\
\hline $\begin{array}{l}\text { Nilai } \\
\text { rata- } \\
\text { rata }\end{array}$ & \multicolumn{3}{|c|}{66,92} & \multicolumn{3}{|c|}{74,03} & \multicolumn{3}{c|}{79,80} & 92,50 \\
\cline { 2 - 7 } & \multicolumn{3}{|c|}{70,47} & \multicolumn{6}{c|}{86,15} \\
\hline
\end{tabular}

Tabel 1. Hasil Tes Membaca Pemahaman Pada pratindakan yang diikuti oleh seluruh peserta didik kelas V sebanyak 26 peserta didik, hasil tes membaca pemahaman pada siklus I menunjukkan bahwa kriteria ketuntasan klasikal belum tercapai. Kriteria keberhasilan ketuntasan klasikal dalam penelitian ini adalah apabila $80 \%$ atau lebih dari jumlah peserta didik dapat mencapai atau melebihi nilai yang ditentukan yaitu 75 . Sedangakan pada siklus ini baru $46,15 \%$ peserta didik yang nilainya $\geq 75$. Oleh karena itu dilakukan siklus II dengan perbaikan yang dihasilkan dari tahap refleksi.

Dari perbaikan-perbaikan tersebut memberikan dampak bagi peserta didik. Pada tes membaca pemahaman siklus II nilai peserta didik mengalami peningkatan. Nilai rata-rata peserta didik pada siklus II mengalami peningkatan sebesar 15,68 dibandingkan dengan nilai rata-rata siklus I, dibandingkan dengan nilai rata-rata siklus I menjadi 92,50 pada siklus II. Dari data yang diperoleh pada siklus II, penelitian ini dikatakan berhasil karena telah mencapai kriteria keberhasilan yang ditentukan, yaitu $80 \%$ dari jumlah peserta didik yang mengikuti pembelajaran mendapat nilai $\geq 75$. Berdasarkan pembahasan dapat dilihat adanya peningkatan keterampilan membaca pemahaman sebelum pratindakan sampai setelah dilakukannya tindakan siklus II. Hasil tes membaca pemahaman setalah dilaksanakannya pembelajaran membaca pemahaman dengan metode SQ3R terus mengalami peningkatan dan menunjukkan bahwa metode SQ3R efektif untuk meningkatkan keterampilan membaca pemahaman peserta didik kelas V SDN 001 Batam Kota.

Hal ini sejalan dengan pendapat Dalman (2013:189) menyatakan bahwa metode SQ3R merupakan cara yang sangat efektif untuk memahami isi bacaan, sehingga teknik ini sangat baik digunakan untuk membaca pemahaman. Keberhasilan tersebut ditunjukkan dengan peningkatan nilai peserta didik.

\section{SIMPULAN}

Berdasarkan hasil penelitian dan pembahasan, dapat disimpulkan bahwa keterampilan membaca pemahaman peserta didik kelas V SDN 001 Batam meningkat dengan menggunakan metode SQ3R. Peningkatan keterampilan membaca pemahaman peserta didik kelas V SDN 001 Batam Kota ditunjukkan dengan adanya peningkatan kualitas proses pembelajaran dan peningkatan hasil pembelajaran. Peningkatan proses pembelajaran ditunjukkan dengan peserta didik lebih aktif dan antusias mengikuti proses pembelajaran menggunakan metode SQ3R.

$$
\text { Peningkatan hasil pembelajaran }
$$

keterampilan membaca pemahaman peserta didik kelas V SDN 001 Batam Kota adalah sebagai berikut. Pada siklus I nilai rata-rata mencapai 70,47 , dan pada siklus II nilai rata-rata mencapai 86,15 . Presentase peserta didik yang mencapai indikator indikator keberhasilan proses dan produk dalam penelitian ini. Sehingga penelitian ini dapat dikatakan berhasil.

Peningkatan yang terjadi dikarenakan dalam proses pembelajaran telah menggunakan metode SQ3R. Adapun langkah-langkah pembelajaran membaca pemahaman dengan menggunakan metode SQ3R pada penelitian ini adalah sebagai berikut. Tahap pertama yang dilakukan siswa adalah tahap survey, yaitu peserta didik membaca secara sekilas teks bacaan yang telah diterima. Membaca sekilas tersebut meliputi membaca judul bacaan, menghitung jumlah paragraf, membaca kalimat pertama dan terakhir setiap paragraf, serta membaca kalimat secara acak. Dengan membaca sekilas tersebut siswa telah mendapat gambaran umum dari teks bacaan dan memancing rasa ingin tahu peserta didik. Selanjutnya tahap kedua yang dilakukan peserta didik adalah tahap question, yaitu membuat pertanyaan terkait dengan isi bacaan. Dengan membuat pertanyaan peserta didik lebih fokus dalam membaca untuk menemukan jawaban dari pertanyaan yang telah dibuat. Tahap ketiga adalah tahap read, peserta didik membaca secara keseluruhan teks bacaan untuk memahami dan menemukan jawaban. Tahap keempat adalah tahap recite, peserta didik menjawab pertanyaan yang telah dibuat, serta membuat ringkasan teks bacaan. Tahap kelima adalah tahap review, yaitu peninjauan kembali teks bacaan, peninjuan kembali dilakukan dengan membahas ulang garis besar isi teks bacaan. Melalui tahap-tahap yang telah dilakukan tersebut peserta didik dapat lebih mudah memahami bacaan dan mengingat isi bacaan lebih lama.

\section{DAFTAR PUSTAKA}

Aris Shoimin. (2014). 68 Model Pembelajaran Inovatif dalam Kurikulum 2013. Yogyakarta : Ar-ruzz Media.

Dalman. (2017). Keterampilan Membaca. Jakarta: PT Raja Grafindo Persada.

Haryadi, NS. (2016). Peningkatan Keterampilan Membaca Pemahaman Untuk Menentukan Gagasan Utama dengan Metode P2R dengan Teknik Diskusi pada kelas $V$ Madrasah Ibtidayah Tarbiyatul Atihfal Wedung Demak. Jurnal Pendidikan Bahasa dan Sastra Indonesia Vol 5(2), 24-29.

Nglimun \& Noor Alfulaiala.(2014). Pembelajran Keterampilan Berbahasa Indonesia. Yogyakarta : Aswaja Pressindo. 
Nugraheni, A.A dan Yunianta, T. (2018). Penerapan Metode SQ3R untuk Meningkatkan Pemahaman Konsep. Jakarta : Genta Mulia

Pebriana, P.H (2017). Peningkatan Keterampilan Menulis Puisi Bebas Menggunakan Pendekatan Kontekstual Siswa Sekolah Dasar. Jurnal Publikasi Pendidikan Vol 7 (Hal : 95)

Razak, Abdul. (2015). Membaca Pemahaman Teori dan Aplikasi Pengajaran. Pekanbaru: Ababil Press.

Sugiyono. (2012). Metode Penelitian Pendidikan (Pendekatan Kuantitatif, Kualitatif,dan $R \& D)$. Bandung: Alfabeta

Surya. Y.F (2018). Penerapan Model Pembelajaran Kooperatif Tipe Team Games Tournament (TGT) untuk meningkatkan hasil belajar Matematika Siswa Kelas V Sekolah Dasar. Jurnal Pendidikan Matematika Vol 02 (Hal : 157)

Widianto, E dan Subyantoro. (2015). Pendidikan Bahasa dan Sastra. Bandung : Alfabeta 